\title{
LEGAL INHERITANCE IN FRANCE AND IN ALBANIA: COMMON ELEMENTS AND COMPARATIVE ASPECTS OF SUCCESSION TRADITIONS
}

\author{
Nertila Sulçel \\ National Registration Center State Institution, Tirana, Albania
}

\section{ABSTRACT}

Inheritance begins with the birth of ownership, and continues with property rights. Inheritance is an ancient tradition, which the Romans recognized in the Twelve Tables (303 BC), in their priority of testamentary rights. Such principles have their origin in a primitive community, although, at that time, there were no genuine inheritance rights. Inheritance is the practice of passing on property, titles, debts, rights, and obligations upon the death of an individual,named the deceased (the person who dies), to the heir, who is the person entitled to receive a share of the deceased's property. This is an action of mortis causa, which happens due to the death of the deceased. The study of inheritance creates interest, because it relates to the law from the time of the deceased's death, despite the advent of any disagreement. Inheritance by law is applied in cases when the person leaving the inheritance has not made a will, or has made a will only for a part of their property, or when the will is declared invalid. The inheritance initiates, when the deceased dies by natural death or civil death. It initiates in the place where the deceased had their last residence. The major economic and political change that occurred in Albania after the fall of the communist dictatorship, was on 1 November 1994, with the enactment of the Civil Code for the Republic of Albania. The third section and articles 316-418 of this code deal with inheritance. The French Civil Code was published on 21 March 1804. In this, the third book covers different modes of acquiring property, and under the title of "Successions" deals with inheritance,from article 718 onwards. The French and Albanian inheritance traditions share similarities and disparities. In this paper, we discuss and compare these two inheritance instruments.

\section{UDC \& KEYWORDS}

- 347.6 - LAW $=$ INHERITANCE $=$ DECEASED $=$ HEIR $=$ DEATH - PROPERTY ॥ OWNERSHIP — LEGAL RESERVATION

\section{INTRODUCTION}

Inheritance is the passing of the property to adecedent's heirs through intestacy. Inheritance law governs the rights of a decedent's survivors to inherit property. The French Civil Code (2013) represents a comprehensive reformation and codification of the French civil laws. Under the ancient regime, more than 400 codes of laws were in place in various parts of France, with common law predominating in the north, and Roman law in the south. The revolution overturned many of these laws. In addition, the revolutionary governments had enacted more than 14000 pieces of legislation. The French made five attempts to codify the new laws of France during the periods of the National Convention and the Directory. Although they completed the draft at the end of 1801, the code was not published until 21 March 1804. The civil code represents a typically Napoleonic mix of liberalism and conservatism, although most of the basic revolutionary gains - equality before the law, freedom of religion, and the abolition of feudalism - were consolidated Inertila_sulce@yahoo.com within its laws. The code reinforced patriarchal power by making the husband, the ruler of the household. The succession is treated in "Book III"under the title of "Successions" from article 718 onwards.

The Civil Code of the Republic of Albania was published on 1 November 1994, after the fall of the communist dictatorship. The inheritance is treated in article 316 and onwards. Both, the Italian and French civil codes, and civil law in general,influenced the Albanian civil code. The main forms of inheritance are legal succession and testamentary succession. In this article, we will discuss the legal inheritance in France and Albania and the difference between these concerning heirship.

\section{Legal inheritance in France}

The French Civil Code (2013)has three books. Book one covers persons, book two property and different modifications of property, and book three the different modes of acquiring property. It is the third book that deals with successions, from article 718 onwards. Succession refers to the transfer of property of a deceased person. Assets are acquired and transmitted through donation, will, orby obligation (in terms of succession). The parties participating in establishing the relationships in the inheritance are the author, who is the deceased usually called de cujus, ( in Latin "is de cujus succesioneagitur", means that of the succession which belongs) and the follower, known as heir,successor, beneficiary or legatee. There are two types of inheritance, public and private. Public inheritance concerns the testator's estate in favor of the community, being the state in modern societies. Private inheritance concerns the property in favor of certain individuals. This system does not exclude the fact that the public community can benefit from the testator's estate through the will. However, this is not in the capacity as a public authority that receives the property's income; benefits it as can benefit anyone other than the heir designated by the decedent. The private inheritance legacy shares legal and testamentary inheritance. In the case of testamentary inheritance, through a unilateral legal act, the will determines the heirs. In the case of legal succession, the law determines the heirs in case of the testator's death. The succession is opened at the point of the deceased's death by natural death or civil death, as stated in article 718 of the French Civil Code (2013). The procedure then involves exercising the heir's right of option. Assets are transferred ipso jure [by law] at the time of death, but such a transfer is not essential. If several persons, respectively named as succeeding each other, perish by the same accident, so that it is not possible to ascertain which of them died first, the presumption of survivorship is determined by the circumstances of the event. In defect of such, this will be by age and sex. If those who perished together were under fifteen years, the eldest shall be presumed to have survived. If they were all above sixty, the youngest shall be presumed to have survived. If some were under fifteen years, and others more than sixty, the former shall be presumed to have survived, according 
to article 721 of the French Civil Code (2013). Disposition and distribution of property through inheritance involves three ways that are defined in article 1002 French Civil Code (2013). These are first by universal legacy, legacy with universal title,and legacy with a particular title. Universal legacy implies universal inheritance and separates into the following categories:

- legacy of all movable and immovable property or of all of the testator's property;

- legacy of all available goods or of a constant quantity of goods;

- legacy of the nue-propriéte (bare ownership, which means that someone has it in usufruct).

Legacy with a particular title means one or more items (goods) specified (Latifi, 2012). Heirs can inherit only if they have the capacity as heir. They can prove their capacity as heir by any means. This includes a sworn affidavit drawn up by a civil law notary, at the request of one or more rightful claimants. This affidavit is considered authentic until proven contrary, according to article 730-3 of the French Civil Code (2013). There are different cases to inherit the estate by heirs: If the deceased was unmarried and without children, the deceased's parents, together with their brothers and sisters, if there are any on the day of the deceased's death, participate in the succession. The estate transfers to the deceased's parents, brothers, sisters, and descendants of the latter If the deceased does not leave any brothers, sisters, or descendants of the latter, their estate is divided equally between their mother and father, according to article 736 of the French Civil Code (2013). If the mother and father die before the deceased, the brothers and sisters of the deceased, or their descendants, succeed them, to the exclusion of other relatives, ascendants or collateral relatives. If the deceased is unmarried and leaves children,the estate is shared equally between the descendants. In this case, children inherit equal portions. If the deceased leaves a spouse, the surviving spouse receives all the estate, where the deceased has collateral relatives. Where there are parents, half of the estate transfers to the spouse, and the other half to the parents. Where the deceased leaves a spouse and children and where there are children of the same parents, the surviving spouse receives, at their choice, either the usufruct of the deceased's assets or the ownership of a quarter of the assets. Where there are children, but not of the same parents, the spouse receives the ownership of a quarter of the assets. If the deceased leaves a spouse and ascendants, half of the estate transfers to the spouse, while the mother and father each receive a quarter. If one of the ascendants is already deceased, the quarter reverts to the spouse. If there are neither ascendants nor descendants, the whole estate transfers to the surviving spouse. Notwithstanding article 757-2 of the French Civil Code (2013), if there are no ascendants, the deceased's brothers, sister or their descendants receive half of the assets included in the succession received by the deceased from their ascendants by way of a succession or a gift. This is the right of reversion. All the other assets transfer to the surviving spouse. If the deceased leaves a spouse and children, the spouse has a right of option. They may choose between the usufruct of all the existing assets, or the ownership of a quarter of the assets, when all the children are born to the same parents, and the ownership of a quarter of the assets in the case of one or more children who are not born to the same parents.
The adopted child inherits as a legitimate child. This happens when there is a full adoption, and even in the case of a simple adoption (Grimaldi, 1998).Children born out of adultery had suffered, until recently, adverse legal and social consequences. In France, a law stating the inheritance rights of a child, born under such circumstances was half of what would have been under ordinary circumstances, remained in force until 2001. France was forced to change it by a ruling of the European Court of Human Rights(ECtHR) and in 2013 the ECtHR ruled that the new 2001 regulations must be also applied to children born before 2001](Tartari,2010). The surviving partner of a non-registered partnership, as well as the surviving partner of a registered partnership, do not have a legal title to inheritance. On the other hand, they can benefit from a legacy or devise. A registered partner is not considered an heir of the deceased. They have only a right of undisturbed possession over the family home after the death of their partner, pursuant to article 763 of the Civil Code. They, therefore,only inherit if they are named as a beneficiary in the deceased's will. Where there are children involved, whether they are born to the couple or not, the available portion of the estate can only be bequeathed to the surviving partner. The available portion varies according to the number of children with a third of the estate allocated where there are two children and a quarter where there are three or more children.

If there are no children, it is possible to bequeath the whole of the estate to the surviving partner, or to a third party, because there are no forced heirs. However, if the deceased's parents are still alive, they may submit a claim on a property that they gave to their deceased child, up to the limit of a quarter of the estate for each parent still alive. Non-registered partners (cohabitees) are not considered heirs. They inherit, therefore, only if they are named as beneficiaries in the deceased's will.

\section{The reserved portion}

There are heirs who can assert their right to a portion of the estate, known as the "reserved portion", which legally transfers to them, according to articles 721 and 912 of the French Civil Code (2013). There is a reserved portion for the deceased's children and a reserved portion for the surviving spouse. Ascendants and collateral relatives are not forced heirs. The reserved portion for the children is half if the deceased leaves one child at the time of their death. It is two-thirds if they leave two children, and three-quarters if they leave three or more children. The reserved portion for the surviving spouse is a quarter of the estate. This occurs only where there are neither descendants nor ascendants, for all successions opened from 1 July 2002. Under French law, only the deceased's descendants (e.g. children and grandchildren; provided they qualify by rank) and spouse are entitled to a reserved portion. Ascendants and collateral relatives do not have rights to reserved portions. These reserved portions, which limit the testator's right to dispose freely of their estate in the form of a will, cannot exceed three quarters of the estate. Forced heirs cannot renounce the reserved portion (unless they renounce the succession). On the other hand, they can waive an action in abatement against excessive donations beforehand. This involves acting on the abatement.

If a direct or indirect gift interferes with the reserved portion of one or more heirs, the gift may be deducted from the available portion, under article 920 of the French Civil Code (2013).Such action may only be instituted by forced heirs within a period of five years after the opening of the succession or within two years after the date of the discovery of the infringement. 


\section{Legal inheritance in Albania}

Part three of the Albanian Civil Code (1994) covers inheritance with the meaning, as an institution of civil law, given in Article 316. This says, "Inheritance is the transfer by law or by will of property (inheritance) of the deceased person to one or more persons (heirs), according to the rules determined in this Code." Inheritance by law applies to cases where the person leaving the inheritance has not made a will, or has made a will only for a part of their property, or when the will is declared invalid. The inheritance is opened when the person leaving the inheritance dies by natural death or civil death. It opens in the place where the person had their last residence. When that is unknown, the inheritance is opened in the place where they had their last known residence. When that is unknown, the inheritance is opened in the place where, all or most of,their property is located. It is regulated in conformity with the law of the time, when it is opened. A person has capacity to inherit if, at the time of the opening of the inheritance, they are alive, or were conceived before the death of the person leaving the inheritance and are born live. It is presumed that a person has been conceived at the time of opening the inheritance, when that person is born within 300 days from the death of the person leaving the inheritance, under article 320 of the Civil Code of The Republic of Albania (1994).

A person's capacity to inherit is related to two conditions: a) to be alive at the opening of the inheritance; and b) to be one of the legal heirs in the case of inheritance by law and to be a testamentary heir in the case of testamentary inheritance. The capacity to inherit even relates to a person, who was not alive on the opening of the inheritance, but was conceived before the deceased's death and was born live (Nuni \& Hasneziri, 2010). When two or more persons are entitled to inherit from each other, and it is not proved which one has died earlier, it is presumed that all have died at the same time, and no right is transferred from one to another. Children born outside of marriage, when parenthood is duly recognized, as well as adopted children, are equal to legitimate children. Even children born out of adultery are equal to legitimate children. The adopted child does not inherit from the family of their origin, nor does that family inherit from the adopted child. The legal heirs are children, the children of the children, the spouse, parents, brothers and sisters, and children of brothers and sisters previously deceased, grandfathers and grandmothers, and other persons previously born, persons unable to work in charge of the person leaving the inheritance, their other kin up to the sixth degree, as well as the state. In the first round named, the children and the spouse,either able or unable to work, are entitled to inheritance, each inheriting in equal parts. In the case where a child has died before the person leaving the inheritance,their inheritance is renounced and their children take their place by substitution and, when for the above reasons they are not legal heirs, those born after them come into the inheritance without limitation. In such an event, the share of the parent who does not inherit is divided among those born after him, in equal parts. In any event, the spouse receives half of the inheritance. When there are no heirs in the abovementioned rounds, the inheritance transfers to the remaining spouse. In the second round, those named are the parents of the person leaving the inheritance, and the persons unable to work, who lived $r$ with that person as members of their family and in their charge for at least one year before the death of the person leaving the inheritance.
When there are no heirs of the second row, those of the third rounds are named in inheritance. These are the persons unable to work in charge of the person leaving the inheritance (as mentioned in article 363 of the Civil Code of The Republic of Albania, 1994), the grandfather, the grandmother, brothers and sisters, and the children of the brothers and sisters, who have previously died. The above mentioned inherit in equal parts, without making distinction between brothers and sisters of the same father, or of the same mother, or between the grandfather and the grandmother on the father's or the mother's side. When the person leaving the inheritance has left their property to neither persons born after, nor parents or other persons born before, nor brothers, nor sisters, nor persons born after them,the inheritance passes to their nearest kin, without distinguishing between father's and mother's line, but in any event not further than the sixth degree. When the person leaving the inheritance has not left any heirs up to the sixth degree, the state is named in the inheritance.

\section{Legal reservation}

The person leaving an inheritance can exclude from lega inheritance neither their minor children nor other minor heirs entitled by substitution, nor their other heirs unable to work if they are named in the inheritance. Neither can the person affect by will,in whatever manner, the part that belongs to those heirs from legal inheritance, except where they have become unworthy to inherit (Biçoku, 2011).Minor heirs who inherit by substitution are the children of the deceased's children, and other descendants that must be minor to inherit. Heirs unable to work are those who are not yet 16 (or 18 years old when they study), males over 65 years old and females over 60 years old, who are invalid in the first and second groups. If the testator affects, by the will, the legal reservation of these heirs, it will not be valid and will be declared invalid by court.

Things in common and differences about legal inheritance between the two countries

In France and Albania,inheritance is also opened when the person leaving the inheritance dies by natural death or civil death. It is opened in the place where this person had their last residence. When that is unknown, the inheritance is opened in the place where they had their last known residence.

The capacity to inherit, according the Albanian civil code, relates to a person who, at the time of the opening of the inheritance, is alive or has been conceived before the death of the person leaving the inheritance and is born live. It is presumed that a person has been conceived at the time of opening the inheritance, when that person is born within 300 days from the death of the person leaving the inheritance. The capacity to inherit even relates to the person who was not alive at the opening of the inheritance, but was conceived before the deceased's death, and is born live.

According the French civil code, in order for succession the party must be alive at the moment at which the succession is opened. Those incapable of succeeding are: a) those not yet conceived; $b$ ) the child who is not born, and likely to live; and c) those civilly dead, which differ to the Albanian civil code.

According to the Albanian civil code, when two or more persons are entitled to inherit from each other, and it is not proved which one has died earlier, it is presumed that al have died at the same time and no right is transferred from one to another. 
Conversely, according to the French Civil Code, if several persons, respectively named in the succession of each other, perish, by one and the same accident, so that it is not possible to ascertain which of them died first, the presumption of survivorship is determined by the circumstances of the event. In defect of such, it is determined by way of age and sex.

In both France and Albania, too children born outside of marriage, when parenthood is duly recognized, as well as adopted children, are equal to legitimate children. Even children born out of adultery are equal to legitimate children.

In Albania, in contrast to France, legal heirs can be persons unable to work and in charge of the person leaving the inheritance.

According to the Albanian civil code, the person leaving an inheritance can exclude from legal inheritance neither their minor children nor their other minor heirs who inherit, by substitution, as well as other heirs unable to work, if they are named in the inheritance (legal reservation). In France, in contrast to Albania,there are reserved portions for both the deceased's children and the surviving spouse. If a person does not respect the reserved portion in a valid will, in France, the heirs can access their reserved portion through a reduction action, which can also affect goods acquired from third parties in the meantime.

\section{CONCLUSION}

Inheritance is the transfer, by law or by will, of property (inheritance) of a deceased person to one or more persons (heirs). The opening of the inheritance occurs when the person leaving the inheritance dies by natural death or civil death. The opening takes place where the deceased last resided. When that is unknown, the opening of the inheritance takes place in the town where they were last known to reside,for the transfer of the estate to the legal heirs. According to the French civil code, the disposition and distribution of property through inheritance can occur three ways: universal legacy, legacy with universal title,and legacy with a particular title. According to the Albanian civil code, inheritance by law is applied in cases when the person leaving the inheritance has not made a will, or has made a will for only part of their property, or when the will is declared invalid. Usually, the capacity to inherit means that the person at the time of the opening of the inheritance is alive or was conceived and born live before the death of the person leaving the inheritance. Children born outside of marriage with parenthood duly recognized, as well as adopted children and children born as a result of adultery are regarded equal to legitimate children. According to both French and Albanian civil codes, the person leaving an inheritance cannot exclude, from legal inheritance, certain heirs that benefit from the legal reservation.

\section{References}

Biçoku, N. (2011). E drejta e trashëgimisë e Republikës së Shqipërisë [The right of inheritance of the Republic of Albania] Tiranë, Albania: Albpaper.

Civil Code of the Republic of Albania. (1994). Retrieved from http://www.cclaw.al/

French Civil Code. (2013). Retrieved from http://www.legifrance. gouv.frl

Grimaldi, M. (1998). Droit civil successions[Civil law estates]. Paris: Libraire de la Cour de cassation.

Latifi, J. (2012, April). Instituti i trashëgimisë në spektrin e vendimeve unifikuese të Gjykatës së Lartë. [Heritage Institute spectrum unifying decisions of the High Court]. Avokatia [The Bar]. Retrieved from http://avokatia.al/

www.journals.cz
Nuni, A. \& Hasneziri, L. (2010). E drejta civile III (Trashëgimia) [Civil Law III ( Heritage)]. Tiranë, Albania: Perrua.

Tartari, A. I. (2010) Trashëgimia në të drejtën ndërkombëtare private shqiptare [Dawn of private international law in Albanian]. Tirane", Albania: Botimet "Kumi". 